\title{
MENINGKATKAN KETRAMPILAN MENULIS KARYA ILMIAH DI MASA PANDEMI COVID-19 DI MTS SALAFIYAH 2 GRESIK
}

\author{
Zahrotus Saidah dan Azizah Giani Rahmah
}

Prodi Ilmu Komunikasi, Fakultas Ekonomi dan Sosial, Universitas Amikom Yogyakarta Email: zahramiftah@amikom.ac.id

\begin{abstract}
ABSTRAK
Mts Salafiyah 2 adalah salah satu dari sekian banyak Madrasah Tsanawiyah yang terletak di kabupaten Gresik Jawa timur. Selama pandemi covid-19 Mts Salafiyah 2 Gresik melaksanakan kegiatan belajar melalui sistem daring sesuai dengan anjuran dari dinas pendidikan Jawa Timur. Untuk itu, demi mengoptimalkan kegiatan belajar, maka Mts Salafiyah 2 Gresik memanfaatkan aplikasi pendukung seperti classroom, hangoutmeet dan zoom. Dan untuk jadwal kegiatan daring disesuaikan dengan jadwal semestinya. Namun di satu sisi, kegiatan ekstrakulikuler dianulir seperti kegiatan ekstrakulikuler KTI (Karya Tulis Ilmiah). Hal ini menimbulkan dilematis sebab di masa pandemi saat ini siswa dapat memanfaatkan belajar di rumah untuk lebih kritis dan cermat memahami konflik sosial dikerana pandemi. Berlandasan pada kondisi tersebut, penulis beserta mitra, yakni Mts Salafiyah 2 Gresik mengadakan pelatihan KTI dengan harapan siswa memiliki pengalaman, pengetahuan serta teknik menulis KTI yang baik dan menarik. Berdasarkan studi kasus tersebut maka kegiatan pengabdian ini mengambil tema pelatihan penulisan KTI dengan memanfaatkan kondisi pro kontra masyarakat terhadap penanganan pandemi di Indonesia sebagai tema pelatihan. Dengan demikian diharapkan dengan adanya kegiatan pelatihan penulisan KTI ini, siswa MTs Salafiyah 2 dapat memiliki kemampuan dalam menulis karya ilmiah.
\end{abstract}

Kata Kunci: Pandemi, EKstrakulikuler, KTI

\section{PENDAHULUAN}

Mts Salafiyah 2 Gresik adalah salah satu dari sekian banyak Madrasah Tsanawiyah yang terletak di kabupaten Gresik Jawa timur. Madrasah ini merupakan madrasah baru yang berbasis pesantren dan juga merupakan bagian dari lembaga pendidikan yang bernaung di bawah payung yayasan Salafiyah Surabaya. Secara umum dalam segi promosi lembaga pendidikan, Mts Salafiyah 2 cukup terbantu dengan adanya alumni dari MI Salafiyah
Surabaya, namun meski tergolong cukup membantu bukan berarti pihak Mts Salafiyah 2 tidak turut mempromosikan sekolahan di lingkungan luar, sebaliknya pihak Mts Salfiyah 2 memiliki gaya sendiri untuk mempromosikan sekolahannya lebih luas lagi yakni melalui aktif atau terlibat dalam setiap perlomba- perlombaan, baik dalam tingkat lokal sampai dengan tingkat provinsi.

Adapun kegiatan-kegiatan yang diikuti oleh pihak Mts Salafiyah 2 Gresik 
antara lain, robotik, puisi, MtQ, Pidato

Bahasa Inggris dan yang terakhir adalah karya tulis ilmiah. Berbeda dengan dengan perlombaan lainnya, keikutsertaan Mts Salafiyah 2 pada lomba karya tulis ilmiah (LKTI) ini cukup baru. Sebab, selama Mts Salafiyah 2 berdiri, perlombaan LKTI merupakan hal baru yang pernah diikuti. oleh karena itu, kegagalan yang dirasakan oleh pihak Mts Salafiyah 2 Gresik saat mengikuti kompetisi LKTI Nasional yang diadakan oleh UNISMA Malang merupakan hal yang lumrah terjadi bahkan menjadi bagian dari evaluasi bagi Mts Salafiyah 2 untuk mengadakan kegiatan ekstrakulikuler KTI (Karya Tulis Ilmiah).

Sebagai informasi, karya tulis ilmiah terbagi menjadi 2 (dua) tipe, yaitu karya ilmiah hasil laporan penelitian dan karya ilmiah hasil tinjauan, gagasan atau ulasan (Casmudi and Pratama, 2019). Adanya dua tipe tersebut menunjukkan bahwa karya tulis ilmiah ini diciptakan untuk melatih seseorang berfikir kritis dan tentunya yang sistematis. lalu bagaimana dengan Mts Salafiyah 2? di Mts Salafiyah 2 sendiri lebih menekankan pada karya ilmiah hasil laporan. Hal tersebut dipilih sebab disesuaikan dengan usia, linieritas dengan materi belajar, dan lain-lain. Oleh karena itu, adanya kegiatan ektrakulikuler KTI diharapkan dapat menjadikan siswa-siswi Mts Salafiyah 2 Gresik memahami dan menulis karya tulis ilmiah. Untuk itu berbagai upaya dilakukan untuk mewujudkan tujuan tersebut, misalnya dengan mengenalkan sejarah karya tulis ilmiah, konsep karya tulis ilmiah, ruang lingkup karya tulis ilmiah dan beberapa motivasi seperti mengenalkan bukti karya tulis ilmiah dari salah satu siswa Mts Salafiyah 2 yang berhasil lolos di semi final. Penting untuk diketahui bahwa MA Salafiyah Gresik pernah meraih peringkat 10 besar di kompetisi KTI tingkat nasional pada acara LKTI Nasional yang diselenggarakan oleh pihak UNISMA Malang (Ashfiyah and Muthohar, 2019).

Selain itu, dengan adanya kegiatan ekstrakulikuler KTI diharapkan dapat memberikan manfaat berupa stimulasi daya kritis siswa dalam mendeskripsikan serta menganalisis sebuah fenomena yang ada di sekitar mereka. Tidak berhenti di sini saja, dengan adanya ekstrakulikuler ini juga diharapkan dapat melatih serta memicu siswa untuk terbiasa dengan menulis laporan hasil riset dengan cara sistematis serta sesuai dengan kaedah penulisan bahasa 
Indonesia yang baik dan benar. Dengan demikian dapat disimpulkan bahwa adanya ekstrakulikuler KTI ini secara tidak langsung menstimulus siswa untuk terbiasa dengan kegiatan membaca buku dan berita, baik dari media massa cetak maupun dari media massa daring. Sehingga secara kontinue budaya membaca siswa akan semakin terasah seiring dengan adanya penugasan yang diadakan di ekstrakulikuler KTI. lebih jelasnya lagi berikut foto kegiatannya:

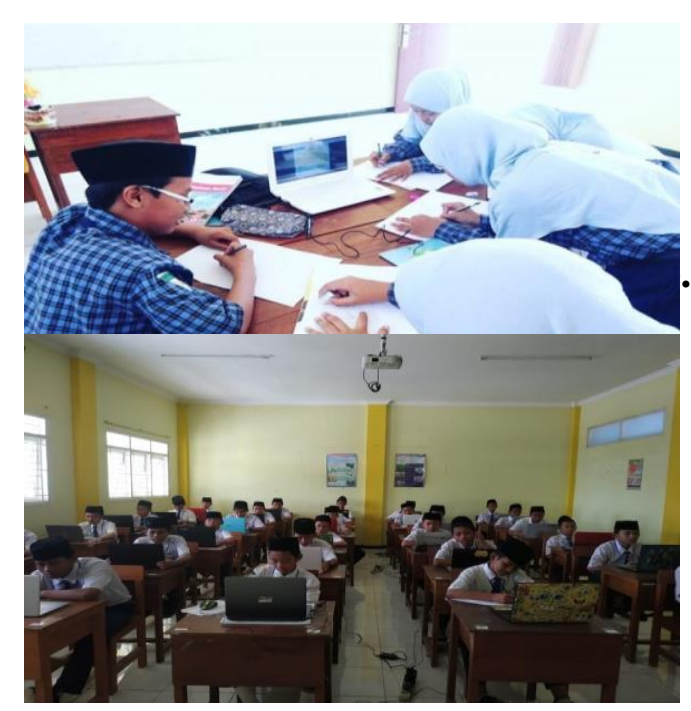

Gambar 2: Kegiatan Ekstrakulikuler KTI (Kelas Putra).

Dengan berpedoman pada tujuan dan manfaat dari pengadaan kegiatan ektrakulikuler KTI, Mts Salafiyah 2 Gresik berupaya mengoptimakan kegiatan ekstrakulikuler KTI yakni melalui pelatihan yang dilaksanakan dua kali dalam seminggu, yakni pada setiap hari rabu dan kamis. Selain itu, Mts Salafiyah 2 Gresik juga memberikan fasilitas berupa laboratorium saintek dan ruang pengajaran selama pemberian materi lain-lain. Akan tetapi, Sejak awal tahun 2020, Indonesia dihadapkan dengan kondisi pandemi covid-19. Kondisi ini nyatanya memberikan dampak sighnifikan bagi berbagai sektor dan salah satunya adalah sektor pendidikan. Selama ini kondisi di Indonesia cukup memperihatinkan sebab penyebaran virus covid-19 terjadi secara massif, yang artinya di beberapa daerah di Indonesia menjadi zona merah yang memiliki arti zona dengan jumlah pasien positif terbanyak. Demi memutus rantai penyebaran virus covid, maka pemerintah memberlakukan peraturan baru yakni bekerja, belajar dan beribadah di rumah. Peraturan tersebut memberikan dampak yang cukup besar terutama bagi sektor pendidikan. Alasannya, selama ini Indonesia menerapkan sistem pembelajaran dengan menggunakan metode tatap muka, namun semenjak adanya pandemi covid-19 sistem pembelajaran di Indonesia beralih ke sistem daring dengan memanfaatkan classroom, zoom 
meeting, google hangout meet, dan lainlain (Ashfiyah and Muthohar, 2019).

Umumnya pembelajaran melalui media daring minim dapat dilaksakanan secara optimal mengingat di beberapa wilayah di Indonesia masih kesulitan mengakses internet, minim fasilitas, jaringan dan lain-lain. Oleh karena itu, tidak semua lembaga pendidikan dapat mengoptimlkan kegiatan belajar daring. Sedangkan untuk Mts Salafiyah 2 sendiri pembelajaran daring masih tergolong efektif hal ini dikarenakan kemampuan pihak madarasah dalam memanajemen pembelajaran daring. Akan tetapi, keefektifan tersebut tidak berjalan selaras dengan kegiatan ekstrakulikuler, sebab selama pandemi kegiatan ektrakulikuler dianulir untuk waktu yang tidak dapat dipastikan sehingga pihak madarasah memutuskan untuk megutamakan kegiatan pembelajaran utama dibadingkan dengan kegiatan ekstrakulikuler. Kondisi ini sangat disayangkan mengingat dengan adanya belajar di rumah siswa dapat memanfaatkan waktu dan tempatnya untuk mengasah kemampuan menulis dan mengalisa terutama mengenai adanya pandemi covid-19 ini.

Berlandasan pada problematika tersebut penulis tertarik untuk mengadakan kegiatan pelatihan penulisan karya tulis ilmiah dengan tema analisis fenomena pandemi covid 19, dengan demikian siswa masih bisa tetap produktif meskipun kegiatan belajar dilaksanakan secara daring serta dengan adanya kegiatan ini diharapkan siswa dapat mengasah dan menganalisa hal-hal yang berkaitan dengan pandemi saat ini.

\section{METODE PELAKSANAAN}

Pada metode pelaksanaanya penulis menyusun 3 (tiga) tahapan pelaksanaan yakni yang pertama di awali dengan kegatan sosialisasi mengenai seberapa penting menguasai penulisan karya ilmiah di tengah persaingan saat ini (Martiningsih, 2018). Namun sebelumnya, untuk mengoptimalkan kegiatan pelatihan ini penulis menspesifikasikan siapa saja yang diperkenankan untuk mengikuti kegiatan ini. Adapun spesifikasinya adalah siswasiswi Mts Salafiyah 2, siswa-siswi yang aktif dalam kegiatan ektrakulikuler KTI, dan siswa-siswi yang tertarik untuk mengikuti kegiatan ini. Kemudian penulis menandatangani kontrak dengan pihak sekolahan sebagai mitra pengabdian dan dilanjutkan dengan mendesain jadwal pelatihan serta mendesain bagaimana skema 
pelaksanaannya. Selama kegiatan diskusi dengan mitra terkait jadwal dan skema kegiatan, penulis dan mitra menyepakati bahwa demi mengoptimalkan pelatihan ini maka kegiatan ini dilaksanakan dua kali pertemuan dengan skema daring (20-21 Agustus 2020). Hal ini disepakati sebab saat itu kondisi wilayah Gresik masih berada di dalam zona merah yang artinya Gresik menjadi salah satu wilayah dengan jumlah pasien postif covid-19 tertinggi di Indonesia.

Dengan demikian demi mempermudah serta mengoptimalkan kegiatan pelatihan penulisan karya ilmiah, maka terlebih dahulu penulis mendesain gambaran yang nantinya akan dibahas atau disampaikan selama proses pelatihan. Selanjutnya, penulis mencatat, mendengarkan serta mendokumentasikan hasil diskusi dengan mitra serta menerima setiap masukan yang disamapaikan oleh mitra yang nantinya masukkan tersebut menjadi bahan pertimbangan selama proses kegiatan pelatihan. Dengan demikian dapat disimpulkan bahwa tahapan dalam kegiatan ini terdiri dari persiapan, pelaksanaan dan evaluasi (Hasbi, Rukhvianti and Gunawan, 2020). Adanya tahapan-tahapan tersebut diharapkan kegiatan pelatihan ini dapat terlaksanakan dengan optimal serta tepat sasaran. Untuk memahami lagi terkait tahapan-tahapan tersebut berikut rincian penjelasannya:

1) Tahapan Sosialisasi. Pada tahapan ini penulis mengajukan proposal pada bulan mei 2020. Dalam proposal tersbeut penulis memaparkan kepada mitra mengenai tujuan dan manfaat pengadaan pelatihan punulisan karya ilmiah di saat pandemi covid-19. Pemaparan tersebut dilakukan dengan tujuan agar pihak mitra memahami pentingnya menstimulus siswa untuk tetap produktif dan cerdas dalam menganalisa situasi dan konflik sosial pada saat ini.

2) Tahapan Pelatihan. Seusuai dengan kesepakatan yang sebelumnya penulis jelaskan maka tahapan pelatihan ini dilakukan selama 2 (dua) kali dengan menggunakan metode virtual, zoom meeting. Selanjutnya untuk pertemuan kedua penulis akan memberikan tugas berupa pengamatan. Jadi, siswa yang mengikuti kegiatan pelatihan ini diberi tugas berupa pengamatan permasalahan sosial yang ada di sekitar mereka lalu hasil pengamatan tersebut dideskripsikan berupa karya 
ilmiah yang sistematis.

\section{3) Tahapan Pembuatan laporan hasil} kegiatan pelatihan. Setelah tahapan pelatihan, penulis membuat laporan hasil pelatihan penulisan. Pada proses penulisan laporan penulis mengumpulkan beberapa dokumen pendukung, baik berupa foto-foto kegiatan, sertifikat serta artikel jurnal pengabdian yang memiliki keselarasan dengan pengabdian yang penulis lakukan. Hal tersebut dilakukan sebagai referensi bagi penulis ketika menulis laporan.

Selanjutnya, pada metode pendekatan yang yang dilakukan selama kegiatan pelatihan ini adalah sebagai berikut (Adisaputera, Hadi and Hutagalung, 2018) :

1) Metode pendidikan adalah metode yang dilakukan dengan cara menjelaskan kepada peserta pelatihan mengenai keutamaan dan pentingnya memahami dan menguasai teknik menulis karya ilmiah yang baik dan benar.

2) Metode pelatihan dan praktik. Pada metode ini penulis mengajak peserta untuk mempraktikkan hasil dari kegiatan pelatihan yang dilakukan selama dua pertemuan. Pada metode praktik ini penulis mendesainya berupa penugasan yang nantinya pada penugasan tersebut didesain kompetisi. Jadi, peserta yang dapat menganalisa dan mendeskripsikan analisanya dengan cara baik, menarik dan sistematis akan mendapatkan hadiah yang sudah disiapkan sebelumnya.

3) Bimbingan atau pendampingan. Pada metode ini penulis dan mitra bertugas untuk memantau peserta, baik dengan cara daring maupun luring serta diperkenankan untuk melakukan konsultasi yang berkaitan dengan KTI. Perihal ini dilakukan demi memaksimalkan kegiatan pelatihan KTI.

\section{HASIL DAN PEMBAHASAN}

Pada kegiatan pelatihan KTI ini penulis mengawali dengan melakukan survei terlebih dahulu di wilayah Mts Salafiyah 2 gresik. Sebagai informasi, kegiatan survei ini dilaksanakan sebelum Kabupaten Gresik menjadi wilayah zona merah sehingga penulis dapat dengan leluasan mengamati kondisi Mts Salafiyah 2 Gresik, baik dari segi fasilitas, siswa, dan mengamati kegiatankegiatan siswa yang berkaitan dengan ektrakulikuler KTI.

Selanjutnya, penulis memetakan 
kondisi pemahaman siswa pada ektrakulikuler KTI. Tahapan ini siswa diberi tugas mengidentifikasi masalah, yakni dengan tahapan-tahapan berikut; mendeskripsikan temuan menarik yang pernah dirasakan siswa melalui tulisan, mengklasifikasikan temuan tersebut dengan menemukan permasalahnya, mengurutkan secara sistematis temuan permasalahan tersebut dengan urutan dari yang terkecil sampai dengan yang terbesar. lalu kemudian memformulasikan temuan tersebut dengan cara memperhatikan nilai kegunaan agar permasalahn tersebut dapat terpecahkan (Mujiwati, Permana and Sahari, 2017). Tahapan berikutnya adalah penulis dan mitra menyusun materi dan rundown. Adapun penyusunan tersebut berlandasan pada hasil pemetaan yang sebelumnya dilakukan oleh penulis selama melakukan survei di lapangan. Hal ini bertujuan agar kegiatan pelatihan KTI lebih optimal, kondusif, efektif atau lebih tepat sasaran. Berikut foto bukti pertemuan antara penulis dengan mitra:

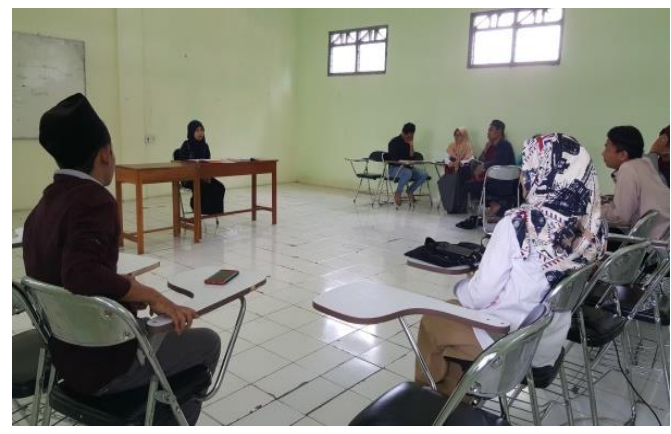

\section{Gambar 3: Penulis dan Mitra}

\section{Menyusun Skema Kegiatan}

Selanjutnya adalah pelatihan. Seperti yang diinformasikan sebelumnya penulis dan mitra memberikan pilihan kemungkinan skema yang digunakan selama kegiatan pelatihan, yakni; skema pertama pelatihan akan dilakuakn secara luring dengan memanfaatkan fasilitas dari sekolahan, kedua skema daring dengan catatan mitra dan penulis terus memantau proses kegiatan pelatihan ini dan menjadikan presensi dan nilai tugas sebagai akumulasi dari nilai untuk kegiatan ekstrakulikuler KTI.

Akan tetapi, menjelang kegiatan pelatihan kondisi di daerah Gresik semakin mengkhawatirkan dan hal ini dapat dilihat dari jumlah data pasien covid di beberapa daerah Gresik. Untuk itu, sebagai bentuk usaha memutus mata rantai penyebaran virus covid -19 , maka kegiatan pelatihan penulisan KTI ini dilakukan secara daring. Untuk itu di hari pertama penulis menyampaikan materi. Pada materi tersebut penulis menekankan pada pengetahuan dasar mengenai KTI dan menjelaskan ruang lingkup, tujuan, manfaat, dan teknik menulis KTI yang baik dan menarik. Berikut foto kegiatan pelatihan KTI 
melalui media zoom meeting:

\section{Gambar 4: Kegiatan Pelatihan}

Daring 1 via Zoom Meeting

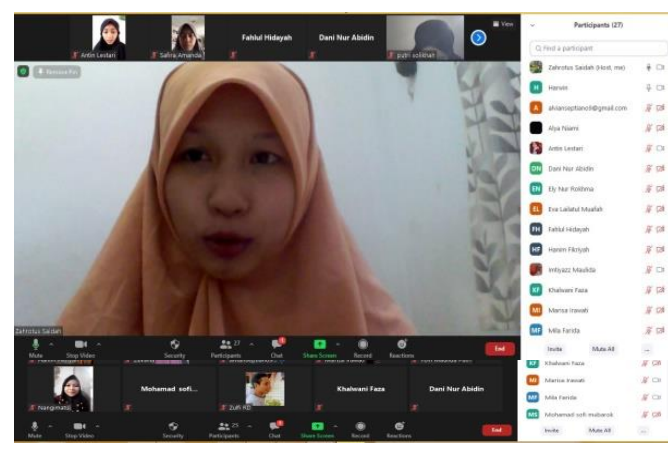

Daring 1 via Zoom Meeting

Selama proses kegiatan penulis memberikan kesempatan kepada peserta untuk bertanya melalui sesi tanya jawab dan hasil dari Tanya jawab tersebut akan direkap dan didokumentasikan untuk menjadi bahan evaluasi kegiatan. Adapun hasil rekaptulasi sesi Tanya jawab tersebut penulis menyimpulkan bahwa selama kegiatan ekstrakulikuler KTI banyak siswa yang terkendala mengawali tulisan. Artinya, mereka merasa kesulitan untuk menemukan kalimat yang tepat dalam menyusun tulisan. Perihal ini menunjukkan bahwa budaya literasi siswa masih lemah dan masih perlu diasah. Dalam hal ini peran guru sangat penting dalam mendampingi siswa untuk meningkatkan kemampuan memahami bacaan serta keterampiran literasi siswa (Setyawan and Gusdian, 2020).

Selanjutnya, untuk menstimulus siswa dalam mempelajari teknik menulis maka kegiatan pelatihan di hari kedua difokuskan pada pratikum. Artinya, penulis memberikan instruksi kepada peserta melalui zoom meeting yang nantinya peserta dipersilahkan mengerjakan tugas tersebut dengan durasi 3 jam, yakni dari pukul 09.00 sampai dengan pukul 12.00 WIB.

Adanya sistem penugasana tersebt dilakukan dengan harapan dapat melatih peserta untuk berani memulai menulis dan juga mengasaya daya kritis peserta serta menambah pengetahuan baru. Secara umum perkembangan ilmu pengetahuan dapat terbentuk dengan adanya sikap keterbukaan pada ilmu baru tersebut dan juga karena adanya sikap gigih dalam mempertanyakan konsesis keilmuan yang masih berlaku (Arta, 2018). Untuk itu dengan adanya pelatihan ini secara tidak langsung dapat menstimulus peserta untuk mendapatkan ilmu pengetahuan baru.

Dengan demikian dapat disimpulkan bahwa kegiatan pelatihan yang dilakukan selama dua hari, yakni 
20-21 agustus 2020 ini menghasil temuan-temuan baru yaitu: kurangnya memanfaatkan fasilitas penunjang yang sudah disiapkan oelh pihak sekolah (2) rutinitas kegiatan menulis seyogyanya dilakukan secara berkala agar siswa terstimulus untuk terus mengembangkan daya kritis mereka (3) kurangnya dorongan guru untuk menstimulus budaya literasi siswa. Padahal guru memiliki peran yang penting dalam menciptakan atsmosfir belajar, sebab guru yang inovatif lebih memungkinkan untuk mencetak generasi yang tidah hanya cerdas dalam hal intelektual saja, namun juga emosional dan spiritual juga (Ratna dan Hengki, 2020).

Berlandasan pada temuan-temuan tersebut, penulis dan mitra mengevaluasi hasil dari pelatihan ini dalam bentuk catatan-catatan berupa hasil rekaptulasi mengenai skala pemahaman siswa dan skala analisa siswa terhadap temuantemuan berupa konflik sosial. Sehingga dengan hasil tersebut dapat menjadi pedoman bagi penulis untuk melaksanakan kegiatan pengabdian selanjutnya. Untuk mitra, catatan catatan rekaptulasi ini dapat menjadi dapat menjadi evaluasi untuk selanjutnya mengadakan kegiatan pelatihan KTI, tidaknya dilaksanakan untuk kalangan siswa saja, namun juga untuk kalangan guru sebab kualitas guru dapat dilihat dari produktifitas guru dalam menulis KTI (Mutia Farida, Dian Agustini, Muhammad Rais Wathani, 2017).

\section{KESIMPULAN}

Berlandasan pada hasil pemaparan kegiatan pelatihan penulisan di Mts Salafiyah 2 Gresik, maka dapat disimpulkan sebagai berikut; pertama, kegiatan pelatihan ini secara eksplisit memberikan dampak signifikan dan hal ini dapat dibuktikan dari hasil penugasan yang dilakukan di pertemuan kedua. Sebelumnya, penulis telah melakukan pemetaan mengenai tingkat pemahaman siswa terhadap karya tulis ilmiah dan hasil yang didapatkan adalah banyak siswa yang masih tidak bisa membedakan bahasa formal dan non formal. Namun setelah pengadaan pelatihan siswa mengalami kemajuan dengan banyaknya penggunaan bahasa ilmiah di dalam gaya penulisan siswa.

Selain itu, pendampingan secara berkala oleh guru terhadap siswanya terutama mengenai dalam hal kegiatan literasi sangat dianjurkan. Sebab, sejauh ini daya literasi siswa Mts Salafiyah 2 
Menganti Gresik tergolong pasif. Hal tersebut dikarenakan kurangnya motivasi serta wawasan mengenai pentingnya membaca di era kompetitif saat ini.

\section{DAFTAR PUSTAKA}

Adisaputera, A., Hadi, W. and Hutagalung, T. (2018) 'Pembinaan kemampuan menulis puisi di padepokan iqro desa kolam kecamatan percut sei tuan kabupaten deli serdang', JPKM: Jurnal Pengabdian Kepada Masyarakat, 26(04), pp. 175-180.

Arta, K. S. (2018) 'Pelatihan Penulisan Artikel Untuk Publikasi di Jurnal Ilmiah untuk Meningkatkan Profesionalisme bagi Guru - Guru di Kecamatan Kubutambahan Kabupaten Buleleng', in Seminar Nasional Hukum dan Ilmu Sosial ke-2, pp. 146-159.

Ashfiyah, A. and Muthohar, A. H. (eds) (2019) Arsip Mts Salafiyah 2 Menganti Gresik. 1st edn. Gresik: Yayasan Salafiyah.

Casmudi and Pratama, R. A. (2019) 'Pelatihan dan Pendampingan Penulisan Karya Ilmiah Remaja bagi Siswa/i SMA/Sederajat di Kecamatan Muara Jawa, Kabupaten Kutai Kartanegara', Abdimas Universal, 1(1), pp. 1-5.

Farida, Muthia. Dian Agustini, and Muhammad Rais Wathani. (2017) 'Pemanfaat Microsoft Word dalam Pembuatan Karya Ilmiah Bagi Guru di Mts Al-Furqon Banjarmasin' Jurnal Pengabdian
Al-Ikhlas. 2 (2) pp. 20 doi. http://dx.doi.org/10.31602/jpai.v2i 2.753

Hasbi, H., Rukhvianti, N. and Gunawan, H. (2020) 'Pembinaan Motivasi Belajar Siswa Menggunakan Metode ARCS', E-Dimas: Jurnal Pengabdian kepada Masyarakat, 11(3), pp. 254-259. doi: 10.26877/e-dimas.v11i3.5653.

Martiningsih, R. (2018) Pelatihan Penulisan KTI Sebagai Wujud Kesadaran Pentingnya Publikasi Ilmiah, pena.belajar.kemdikbud.go.id. Available at: http://pena.belajar.kemdikbud.go.i d/2018/08/pentingnya-publikasiilmiah/.

Mujiwati, E. S., Permana, E. P. and Sahari, S. (2017) 'Pelatihan Penulisan Karya Ilmiah Untuk Guru Sekolah Dasar Pada Anggota Gugus 1 Kecamatan Ringinrejo.', Jurnal Abdinus, 1(1), pp. 53-68.

Ratna and Hengki. (2020) 'Pelatihan Metodologi Penelitian dan Penulisan Karya Tulis Ilmiah Terhadap Guru-Guru SD di Handil Bakti, Desa Semangat dalam Kec. Alalak Kab Batola, Jurnal Pengabdian Al-Ikhlas 6 (2) pp.276. doi http://dx.doi.org/10.31602/jpaiuni ska.v6i2.3933

Setyawan, D. and Gusdian, R. I. (2020) 'Penguatan Habitus Literasi: Sebuah Cara Pendampingan Tim Literasi Sekolah (TLS)', E-Dimas: Jurnal Pengabdian kepada Masyarakat, 11(3), pp. 299-306. doi: $\quad 10.26877 / \mathrm{e}-$ dimas.v11i3.4263. 
Jurnal Pengabdian Al-Ikhlas

ISSN : 2461-0992

Volume 7 Nomor 1, Agustus 2021 